\title{
INNOVATION IN ENVIRONMENTAL ENGINEERING EDUCATION AT REZEKNE HIGHER EDUCATION INSTITUTION
}

\author{
Gotfrid Y.Novik \\ Prof., Dr. hab. \\ Rezekne Higher Education Institution, \\ 90, Atbrivoshanas al., Rezekne, LV - 4600, Latvia \\ Phone +3714625258 \\ Fax +3714623709 \\ Email-novik@cs.ru.lv
}

\begin{abstract}
The paper discusses the elaboration of new study program and curricula in Environmental Engineering at the Rezekne University (RU).

The main goal of the Program is to prepare new formation of Environmental specialists - Ecotehnologists, who are able not only to control pollution of Enviroment, but to prevent it on the early stages by applying in industry ecologically safe technologies.
\end{abstract}

\section{INTRODUCTION}

The integration of Latvia's educational system into European and International systems touches upon a whole string of problems, whose effective resolution could recognizably intensity the process.

At the same time Latvia and its Eastern region - Latgale especially has national and local pecualirities. The Rezekne University has worked out a concept, which could best satisfy regional conditions and on the other side correspond to the standards of higher education accepted in other countries.

The analysis revealed that presently exist various and totally different : approaches to the functioning of higher education not only between countries, but also within the borders of one country. Right now 
it is difficult to determine higher education criteria that are constant and acceptable to all countries.

The question is often discussed: what is the importance of the bachelor's degree and what is a professional person with higher education? Is a baccalaureate less educated than, let's say, an engineer? In general, where is the need for one kind of person where for the other, where are their jobs, will their be a demand for their skills in the economic branches? Answers to these questions are determined by the amount and depth of acquired knowledge in all training systems.

Considering this situation and based on materials about the work of higher educational institutions in the Republic of Latvia, RU tried to formulate the basic theses of its concept.

\section{THE PRINCIPLES OF RU CONCEPT}

The following presumptions were made. First of all, higher education is a complex system of knowledge in a particular field of science containing such a level of development and range that provides the possibility for the acquirers of this knowledge to directly incorporate it into the highest level activities of the field.

Secondly, the bachelor and graduate of the professional school are completely equal specialists with higher education. The only difference is that of theoretical or practical orientation. The bachelor is a person, who has gained higher education in a particular field with emphasis on its theoretical base, mastered scientific research methods, learned fundamental sciences in in-depth courses, and can perform scientific research and theoretical work in his field. The academic degree of the baccalaureate is certified by the bachelor's diploma, which is issued after the successful acquisition of the bachelor's study program, passing of the baccalaureate exam and defense of the dissertation. The baccalaureate's possible work places: scientific research institutions, company laboratories and analytical canters, experimental and theoretical research, and teaching institutions.

A specialist - professional with higher qualification is a person who has gained higher education in a particular field with emphasis on its practical work, deeply understands the organization and methodology, modern machinery and technology of work in this field, and is able to satisfy the demands of this field's development and improvement. The qualification of the specialist-professional is certified by the higher 
education specialist diploma, which is issued after the successful completion of the professional study program and defense of a qualification dissertation. The possible work places of a specialistprofessional: companies, the production and service sphere, institutions, firms, banks, school, secondary educational institutions.

This definition for us fully renders concrete the essentials and differences of the baccalaureate and the professional and specifies the range of knowledge and work places of each specialist. Of course there could be other views on this subject, but if we keep to this definition, then it is clear that the learning process has to be organized in a particular way. First of all, it is clear that professional training is not the subsequent stages after the acquisition of the bachelor's degree. The training has to take place parallely. The ideal situation would be that each orientation would have totally its own study program beginning with the first year. In our conditions, this is, on one hand, practically difficult to carry out, and on the other hand, not so attractive to the students, because it narrows the choices.

That is why the RU concept states that the acquisition of higher education takes place in parallel fashion with both theoretical (baccalaureate) and practical (specialist - professional) orientations. The study plan for each particular field is unified, but all courses are divided into three groups:

F: fundamental, general education courses, which have to be taken by both baccalaureate and professional candidates;

B: academic educational courses, which are obligatory for all B.A. candidates;

P: professional educational courses, which are obligatory for all candidates seeking specialist qualification.

Any student during the first semester can decide upon his desires and abilities and choose either B or P or take courses in both groups at the same time. In the first instance, the student in the last semester of studies takes the baccalaureate exam and defends his dissertation.

In the second instance, the student completes at least an 8-week internship during the study program and prepares and defends his specialist dissertation. 


\section{THE DEVELOPMENT OF ENVIRONMENTAL ENGINEERING}

In Latvia as in the whole world the industrial pressure on the nature is increasing continuosly from year to year. And there is relatively little effect from all efforts applied by Environmental professionals and scientists in protection nature from pollution and destruction.

Such situation is due to division specialists activity in numerous considerable isolated parts with no very tight bonds between them such as environmental control and monitoring, treatment, renovation, etc. At the same time it is very important to unite all efforts in solving key problem - to work out scientifically based principles and methods of innovative and alternative technologies, which do not destroy ecosystems and are ecologically balanced (we name it "ecotechnologies").

It is the motive why on the basis of considered concept the Rezekne University started to prepare specialists in Environmental Sciences and Technology (Bachelor's and Master's degree and Engineers). We have created a new original study program and curricula for students. The program consists of 3 main blocks of subjects: Fundamental Sciences and Humanitaes (F), General Environmental and Engineering Sciences (F), Special Environmental Sciences (B) the teaching of Modern Technology (P).

The main goal of the program is to prepare specialists, who are able to control pollution of Environment as well as to work out, apply in industry and agriculture and exploit new ecologically safe technologies.

In the curricula " $F$ " courses include at first Mathematics, Physics, Chemistry, Computer Sciences, Economics, Foreign Languages and at second - Ecology, Nature Resurces, The Chemistry of Environment, Anthropogenetic Processes, Ecotoxicology, the Quality of Environment and some others - total 60 credit points.

"B" courses include Demecology, Synecology, Experimental Ecology, Biogeochemistry, Radiobiology, Limnology and other special courses - total 40 credit points.

"P" courses include Ecology, Sozotechnics, Environment protection technology, Systems of Ecological Monitoring etc. (40 c.p.)

During the last three semesters students are able to choose special profilization courses in one of the next branches: the Industry of Foods, Forest Industry, Civil Engineering, Mining Engineering, the Industry of Tourism. (60 c.p.)

The students are able to choose next schemes of studies: a) 3 year Bachelor's programm +1 year professional studies; b) 4 year intensive 
paralelly Bachelor's and Engineer's studies; c) 3 year Bachelor's programm and 2 year Master's degree programm.

Presented programm guarantee that our Bachelors and Engineers will be educated in the next fields of Environmental Science and Technology.

- The general principles of the ecologically balanced technologies (ecotechnologies).

- The environment control systems in industrial and agricultural plants.

- Pollution prevents systems in plants.

- Remediation and treatment of water, soil and air."

- Utilization of refuse and recycling of materials in industry.

- Environmental quality parametres and their determination.

- The problem of ecologically pure products.

At the same time they will complete full course of special technology and will be able to work as Engineers and Technologists in the concrete area of industry:

\section{REFERENCES}

1. Silineviča I., Noviks G. The concept of Higher Education at the Higher School in Rezekne, Humanities and Social Sciences. Latvia, Higher Education in Transition, University of Latvia, Riga, 3 (8), 1995. - 63. 67. P.

2. Patrick J. Core Ideas of Dermocratic Civil Education and the Great Transformation in Central and Eastern Europe. - Indiana University, Bloomington, 1996. - 1. - 38. P.

3. Conrad C. Governance and administration of colleges and universities. Introduction to Higher and Post secondary Education. - University of Wisconsin - Madison, 1996. -1. - 171. P.

4. Evalution of Higher Education in the Nordic Countries, ed. Smeby, J.Ch., Nordic Council of Minsters, Copenhagen, 1996. - 21 - - 31: P. 